(Paper No. 3940.)

"Experiments on the Strength of Plain and Reinforced Concrete Slabs."

By Stephen Mitchel Dixon, M.A., B.A.I., M. Inst. C.E., and Percy Willifam Villiers, M.Sc., Stud. Inst. C.E.

Bотн plain and reinforced concrete slabs supported at their four edges are used extensively in floor construction. The analysis of the stresses in such slabs carrying either concentrated or uniform loads, would be a very complicated piece of work, and the results obtained would probably not be applicable to ordinary practice. For this reason the following series of experiments was carried out, in order to obtain some practical information as to the transverse strength of such slabs. In these tests the slabs were supported either on all four edges or on two opposite edges, and three types of loading were applied; namely, a uniform load distributed over the upper surface of the slab, a concentrated load and an impact load.

In this preliminary set of experiments it was determined to limit the width of the slabs to 20 inches. This dimension was fixed upon since it was intended to use the 50-ton testing-machine in the laboratory for applying the concentrated loads. The thickness decided upon for the slabs was $2 \frac{1}{2}$ inches; the reinforcement, if any, being placed $\frac{1}{2}$ inch from the lower surface. The proportions of the concrete were $1: 2: 5$ by volume.

\title{
Testing Apparatus.
}

As it was decided to test most of the slabs by the method of uniform load, it was first of all necessary to design a special apparatus, which is shown in Figs. 1. This was designed for the application, by means of water pressure, of a uniformly distributed load up to 20 tons, on the surface of a slab 20 inches square, and of any thickness up to $3 \frac{1}{2}$ inches; being arranged so that the slab might 
be supported either on all four edges or on two only, like a beam. The slab is supported on a cast-iron frame, which is 24 inches square, the width of the supports is 1 inch, and the clear span is

Figs. 1.

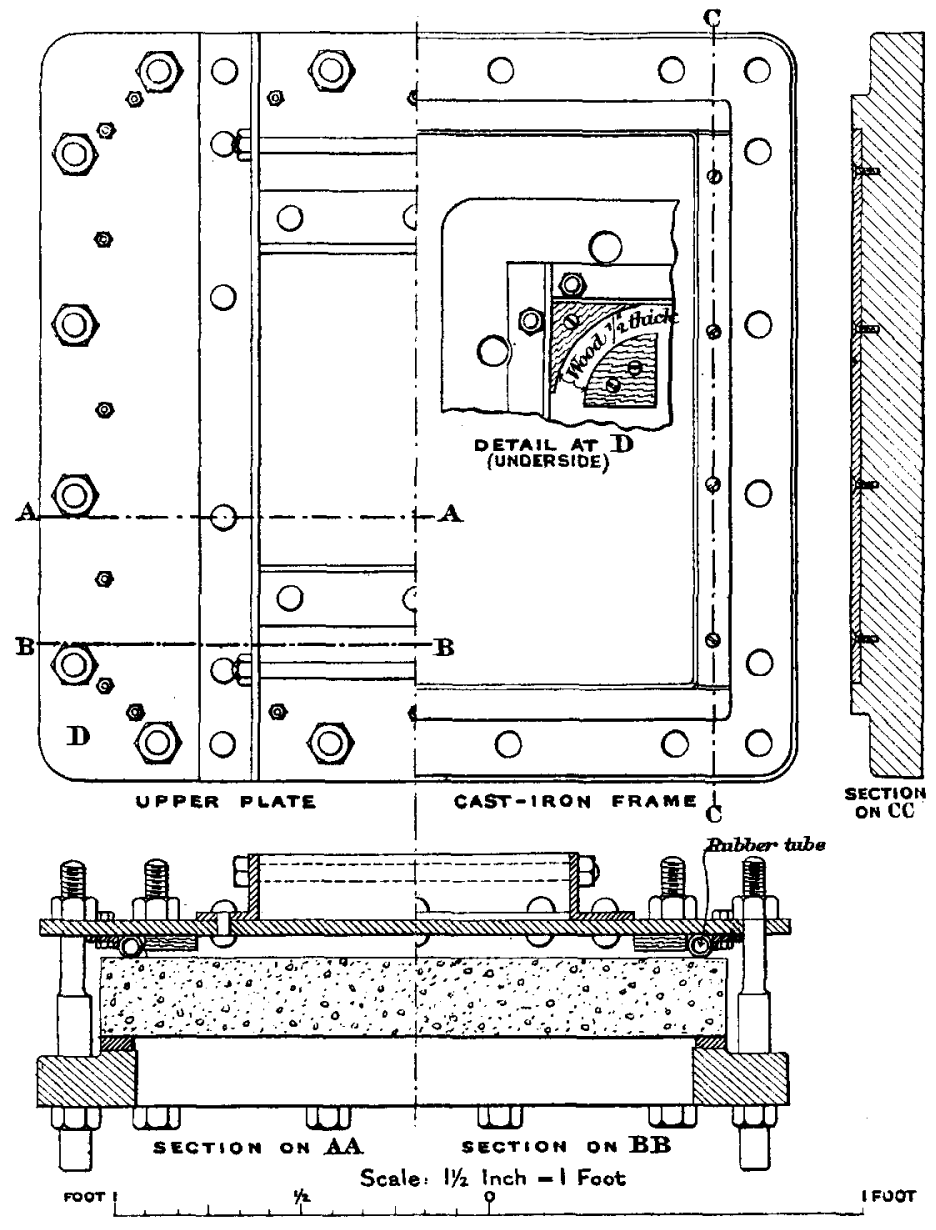

Apparatus for Testing tNDER UntForM Load.

18 inches. Two opposite supports consist of wrought-iron strips measuring 18 inches by 1 inch by $\mathrm{T}^{7} 6$ inch, pinned in place; the bearing surfaces being all machined, and practically in one plane. When these strips are removed the slab may be supported on two 
edges instead of on four. About $\frac{5}{8}$ inch above the upper surface of the slab is bolted a steel plate 24 inches square, and $\frac{1}{2}$ inch thick, stiffened by angle-bars. This plate is attached to the cast-iron base by sixteen bolts.

Between the slab and the plate is a water-tight joint which runs round the upper edges of the slab. Water at any desired pressure is admitted to the space between the upper surface of the slab and the steel plate, the pressure being noted by a suitable gauge. In this way an absolutely uniform load can be applied above the slab; the intensity of the load in pounds per square inch being read directly from the gauge.

The water-tight joint consists of a rubber tube of suitable length with a slit about 2 inches or 3 inches long in each end, the two ends being opened out flat and vulcanized together in a simple lap joint. When this tube is placed between the two flat surfaces and squeezed up slightly the vulcanized part forms a $U$ section. When the water is admitted above the concrete it flows into the inside of the tube, and forcing the sides of the tube against the concrete and the steel plate, forms a water-tight joint. The small angle-bar placed behind the tube prevents it from being forced out sideways. With this joint there is no difficulty in maintaining any requisite pressure, though in some cases, owing to the roughness of the surface of the concrete, there was a certain amount of leakage; this was unimportant, however, as most of the tests were carried on out of doors. The water pressure, about $100 \mathrm{lbs}$. per square inch, was obtained from the town mains, and was brought to the apparatus by a flexible pipe. Some 6 inches before the junction a branch exhaust-pipe, fitted with a stop-cock, was connected to the supply-pipe, so that when opened the water escaped before reaching the space above the slab. By gradually closing this stop-cock the velocity of the water in the pipe was reduced, and the pressure could thus be raised till it was sufficient to break the slab. It was found by this arrangement that the pressure could be regulated in a much more satisfactory manner than by connecting the supply-pipe directly to the apparatus, and regulating the pressure by means of the tap.

\section{Manufacture of Stabs.}

The first few slabs, Nos. 1 to 21, were made with some cement which had been in storage a considerable time, and had deteriorated owing to exposure to damp. The tensile strength of this cement was $474 \mathrm{lbs}$. per square inch at 28 days.

For slabs Nos. 22 to 29 Associated Portland Cement Manu- 
facturers' cement was used, and for the next series, Nos. 30 to 113 , their "Ferrocrete" brand was employed. Tests on these cements at 28 days showed tensile strengths of $601 \mathrm{lbs}$. and $578 \mathrm{lbs}$. per square inch respectively; the setting times were 11 hours and 8 hours respectively.

All the sand used was from Leighton Buzzard. The mechanical analysis of this sand is plotted on Fig. 2, and shows that the greater quantity of the grains were of medium size.

To determine whether the sand should be washed before use a series of tensile and compressive tests was made on 3-to-1 briquettes

Fig. 2.

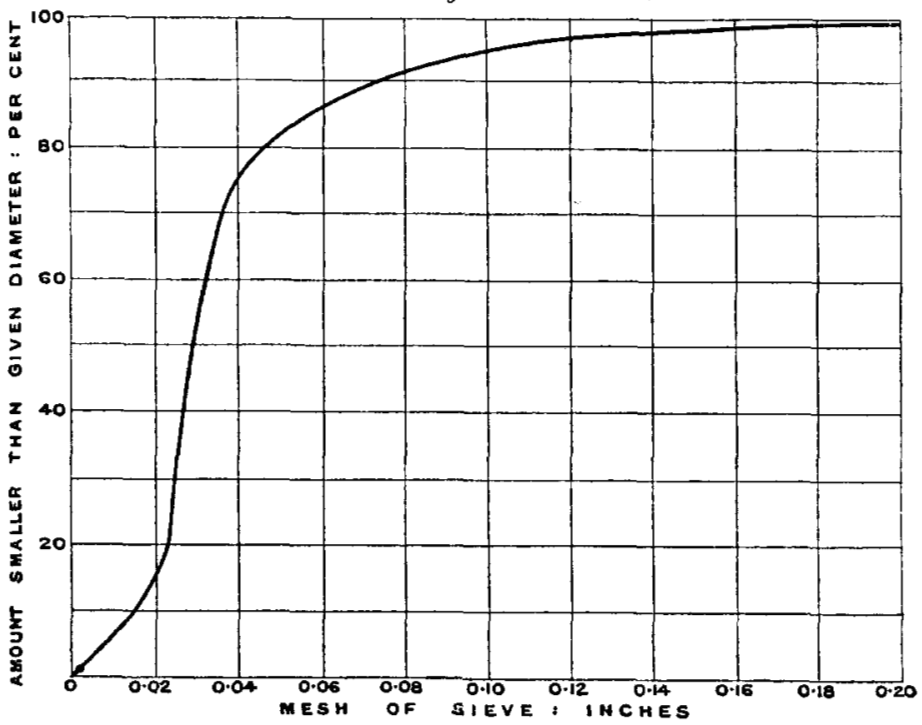

Mechanical Analtsis of Sand.

and 3-inch cubes. The results, however, showed practically no difference in the strengths of specimens made with washed and unwashed sand, and it was decided to use the sand unwashed. The only thing against the sand was the rather uniform size of the grain; a sand composed of fine and coarse grains would have been preferred.

The aggregate consisted of gravel obtained in the University grounds. It was screened so as to pass a $\frac{5}{8}$-inch screen, and to be retained on a $\frac{1}{5}$-inch screen; most of the stones, however, were about $\frac{1}{2}$ inch in diameter. As the gravel contained very fine sand adhering to it when delivered it was all washed. 
Concrete was mixed in the proportions of $1: 2: 5$ by volume; but since the measurement of cement by volume is not very satisfactory (the amount varying with the method of filling) the weight of the required volume of cement was found once for all. The cement required for each batch of concrete was weighed out, the sand and gravel being measured by volume.

All the concrete was mixed very wet in order to ensure that the reinforcing metal should be properly surrounded, and also that the surface of the slab was sufficiently smooth. The ultimate compressive strength of this concrete as determined from a series of tests was $1,250 \mathrm{lbs}$. per square inch, at 3 months; and it had a modulus of elasticity of $1,260,000 \mathrm{lbs}$. The average apparent adhesion of No. 11 iron wire when rusty and embedded in 6 inches of this concrete was 200 lbs. per square inch.

The reinforcement used for most of the slabs was "Expanded Metal" of various weights per square foot, the size of the mesh being in most cases $1 \frac{1}{2}$ inch (measured the short way of the mesh). The ultimate tensile strength of this metal was 66,000 lbs. per square inch. A few slabs were reinforced with one or more layers of ordinary wire-netting, of $1 \frac{1}{4}$-inch mesh, weighing $0.123 \mathrm{lb}$. per square foot.

It was also proposed to make a series of tests employing the Monier type of reinforcement, using various percentages of metal. The wires in this reinforcement are crossed at right angles, forming a square network. Some preliminary experiments on the adhesion of wires to concrete showed that slabs reinforced in this manner would probably fail by the reinforcement slipping through the concrete, unless a large number of small wires were used, so that only six slabs were reinforced in this way. Three of these slabs were reinforced with straight wires of hard-drawn iron, No. 11, S.W.G., spaced $1 \frac{1}{2}$ inch apart, or twenty-four wires in all; while in the other three the wires were interwoven in the Cottancin method. The ultimate tensile strength of the wire used was 70,400 lbs. per square inch, the yield-point being about $62,000 \mathrm{lbs}$. per square inch.

The slabs were made in wooden moulds on a flat concrete floor, two layers of felt paper being placed on the floor to prevent the slabs sticking. The moulds were removed when the concrete had set, but the specimens themselves were left to harden for about 4 days. A compression specimen was made from each batch of concrete. The specimens were stored for 3 months before testing, and were kept damp all the time, a hose being played on them every few days. 
Tests.

Distributed Loading.-In order to obtain as good a bearing as possible, the supporting edges of the testing apparatus were covered with a mixture of plaster of Paris and water, and the slab was instantaneously lowered on to its bearing by means of a lever arrangement. When the plaster had set the specimen was tested. The results of these tests are shown in Tables I to VII of the Appendix.

In Table $I$ are shown the results of tests on slabs of plain concrete $2 \frac{1}{2}$ inches thick, of the three varieties of cement already described, the manner of supporting these slabs being noted. In Table II and Fig. 3 are shown the effects of variation in thickness

Fig. 3.

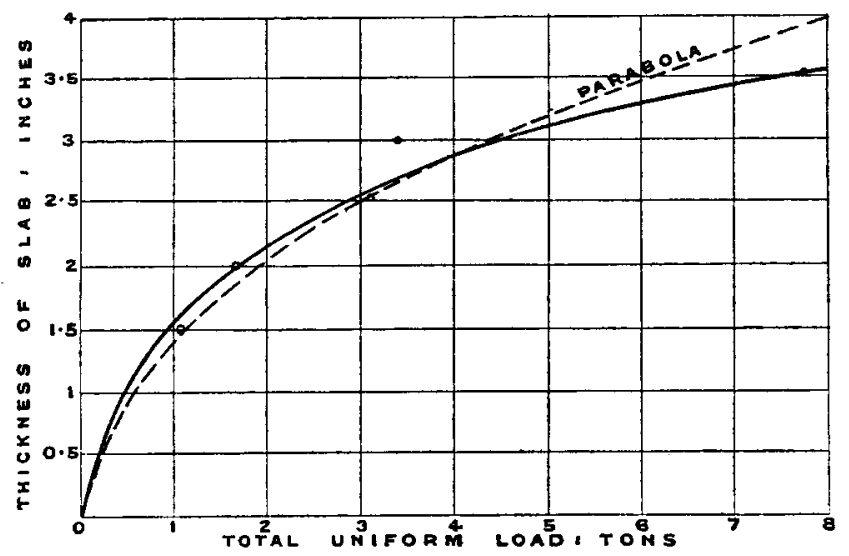

Effect of Thickness on Strength.

on the strength, the slabs being supported on four edges. Table III shows the results obtained when galvanized-iron wire-netting was used for reinforcement.

Tests on slabs with expanded-metal reinforcement were carried out to see if it was possible to find by experiment the economical percentage of reinforcement, and to compare the results obtained with those derived from the ordinary theory of reinforced beams. The percentage of reinforcement used in the tests varied from $0 \cdot 18$ to $0 \cdot 79$ per cent. The expanded metal used was all of $1 \frac{1}{2}$-inch mesh, except No. 19, which was of $\frac{3}{4}$-inch mesh. Each sheet was weighed, and its weight per square foot found. It was thought at first that it would be impossible to place the reinforcement at the 
same depth for all the slabs; and it was proposed therefore to ascertain the exact position of the reinforcement in the slab after fracture, and then to apply a correction in each case if necessary. To ascertain this correction a set of specimens was made having the reinforcement (No. 22 expanded metal) placed at various distances below the top surface. The results of these tests are given in Table IV. It was found, however, when the complete series of reinforced slabs was tested, that the extreme variation in the depth of the slab, or in the position of the reinforcement, was not more than $\frac{1}{16}$ inch. If a curve is plotted from Table IV it will be found that this variation makes a difference of $3 \frac{1}{2}$ per cent. Owing to this comparatively small difference, and to the fact that three

Fig. 4.

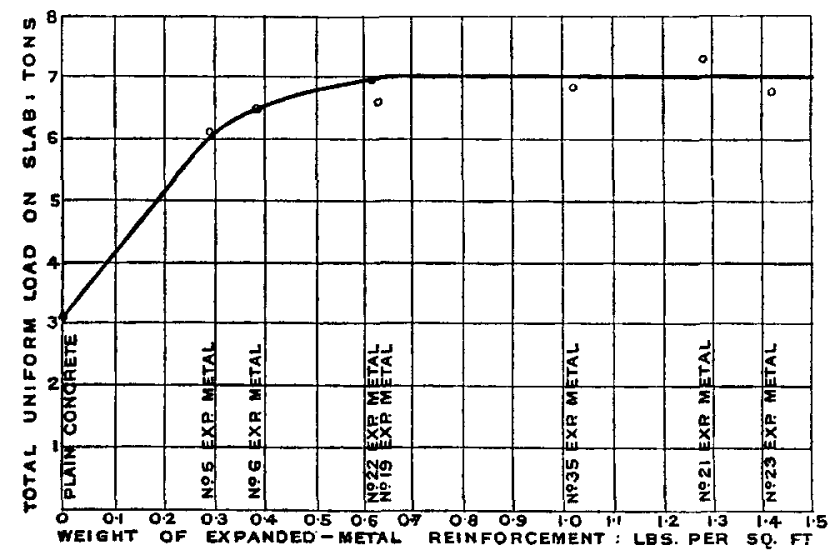

Effect of Amodit of Reinforchiment on Strength.

specimens were made with each kind of reinforcement, of which the average result was taken, it was decided not to introduce any correction. Curves were plotted with and without the correction, and the shapes of the two curves, although not coincident, were essentially the same.

In Table $\mathrm{V}$ is shown the variation of the transverse strength with the amount of reinforcement employed, the slabs being supported on four edges; the results from this Table are plotted in Fig. 4. In Table VI are given the tests on reinforced slabs supported on two edges only. Most of these specimens were placed, as recommended by the makers, with the long way of the mesh perpendicular to the supports, but the last four specimens were 
supported with the long way of the mesh parallel to the supports. In Table VII are given the results of tests on the six slabs reinforced by iron wire in the Monier and Cottancin methods. In the case of at least two of the last three specimens it was noticed that the slab, though cracked, was still able to support a considerable load (about 5 tons). This, together with the method of failure, will be alluded to later. The Monier slabs probably failed through lack of adhesion; the Cottancin slabs through the partial straightening out of the reinforcement.

Concentrated Loading.- Two series of tests with concentrated loads were made. In the first a load distributed evenly along the centreline of the specimen was applied. The specimen was supported on two edges only, and the line of the load was parallel to the supports. In the second series the specimen was supported on the four edges, and the load was applied at the centre, being distributed over a $3 \frac{1}{2}$-inch square. The results of the tests on plain concrete slabs are shown in Table VIII of the Appendix, and those obtained from tests on reinforced concrete slabs in Table IX.

Impact Tests.-For these tests a cast-iron ball, weighing 9 lbs. 5 ozs., was used. The specimens were supported on four edges on a thin layer of plaster. The support used was the base of the hydraulic testing-machine, which weighed about $120 \mathrm{lbs}$. and was supported firmly on four concrete blocks. Owing to the rigidity of the support it was assumed that all the energy of the falling weight was absorbed by the specimen. The weight was suspended by a string exactly over the centre of the slab to be tested, and when adjusted to the required height was released by burning the string. The results of these tests are given in Table X.

Impact tests on a material like concrete, particularly in thin slabs, cannot be expected to give consistent results. The ideal method would be to find the limiting height from which the weight could be dropped without breaking the specimen at the first blow. This, however, would require a very large number of specimens.

From the Table it is evident that a number of the light blows would produce the same effect as one or two heavier ones. It follows therefore that each blow, however small, had a deteriorating effect on the specimen, and for purposes of comparison the total number of foot-pounds expended in breaking each slab is given.

A slab was considered to have failed as soon as the first crack was visible. A reinforced specimen, even when cracked, will withstand many more blows without being broken up. The first crack was always parallel to the long way of the mesh of the expanded metal, showing that failure had probably occurred by the stretching 
of the metal sideways. The average energy required to break a plain slab was 72 foot-lbs., whereas to crack a reinforced slab required 152 foot-lbs.

Remarks on the Manner of Failure of the Slabs Tested in Various Ways.-All plain concrete specimens failed, as would be expected,

Figs. 5.
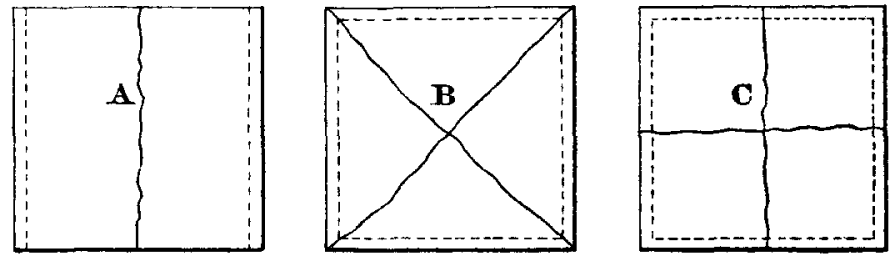

o L a .

CONGRETE
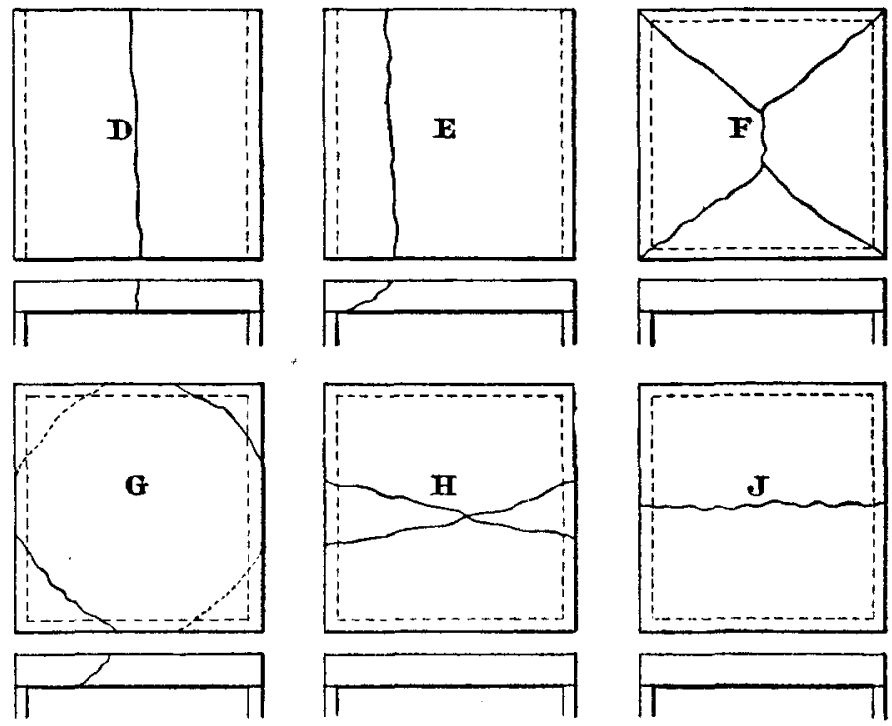

Methods of Failure,

by direct tension. A sketch of the fracture of each specimen was made at the time the slabs were broken, and it was found that there were ten typical forms of fracture. Sketches of nine of these are shown in Figs. 5. Plain concrete specimens when supported on two edges and loaded uniformly failed as shown at $A$, and when supported on four edges failure took place by cracks between the 
opposite corners, as shown at B. When loaded with a concentrated or impact load the cracks are parallel to the sides, as shown at C. It is evident, therefore, that the distribution of the stress in the specimen is different in the two cases.

Reinforced specimens may fail in any of the five following ways :-

By fracture or stretching of the reinforcement, the yield-point being exceeded; that is, by direct tension.

By compression of the concrete.

In the case of a mesh reinforcement like expanded metal where the strands are not parallel to the supports, by stretching of the mesh in one direction accompanied by a contraction of the mesh in a direction at right angles, the elastic limit not being exceeded.

By the reinforcement slipping in the concrete.

By diagonal tension, which shows itself by cracks starting at or near the support, and running diagonally at an angle of about $45^{\circ}$ towards the compression surface.

All these methods of failure, except possibly the secondcompression of the concrete-were met with in the tests on the reinforced slabs. The manner of failure is important, as it is only when the failure is by direct tension or compression that the reinforced concrete beam theory holds.

Generally speaking, specimens reinforced by light expanded metal, or galvanized-iron netting, failed by direct tension. If heavily reinforced with expanded metal they failed by diagonal tension.

A direct-tension fracture with light reinforcement (slab No. 113) is shown at D in Figs. 5, the long way of the mesh being perpendicular to the two supports, and the load being either uniform or concentrated along the centre-line. Slabs Nos, 48, 49, 56, and 57, Table VI, failed by the third method-stretching of the mesh. These slabs, as indicated, were supported on two edges only and with the mesh laid the wrong way, that is, the long way of the mesh was parallel to the supports. The strength of these slabs was slightly inferior to that of plain concrete similarly supported. At $\mathbf{E}$ is shown a typical failure by diagonal tension, such as occurred when a heavily reinforced slab was supported on two edges, and carried either a uniform or concentrated load. Slabs Nos. 45, 46, 54, and 55, Table VI, failed in this way. With specimens supported on four edges it was more difficult to distinguish between failure by direct and diagonal tension. Typical failure by direct tension is shown at F, Figs. 5, and that by diagonal tension at $G$. The cracks in this method of failure were as a rule extremely regular and circular; when viewed from the side they had a diagonal direction.

A difficulty lies in the fact that both the straight and circular 
cracks occurred almost simultaneously, forming a combination of $F$ and $G$, and unless the pressure was removed at the instant of failure it was impossible to say which cracks occurred first. When this was done with lightly reinforced specimens the failure was that shown at $\mathbf{F}$; whereas with heavy reinforcement it was that shown at G. It is clear that if the load were left on a specimen which had failed by the circular cracks, then a second series of cracks running between the opposite corners would probably form. When supported on four edges and loaded with a concentrated load the mesh of the reinforcement generally stretched sideways. The typical failure is shown at $\mathbf{H}$. The metal also stretched sideways in the specimens tested by impact as shown at $J$.

\section{Conclustons Derived from the Tests.}

In considering the relative strengths of various specimens it is obvious that only those specimens which failed in a similar manner must be compared together.

Plain Concrete Slabs.-These specimens all failed in a similar manner, and in Table XI are compiled the results of all the observations given in Tables I and VIII. It will be seen that the ratio of the strength when supported on four edges to the strength when supported on two edges equals that of item 8 to item 7, i.e., $2 \cdot 46$, provided that the slabs are well bedded. When the bedding is inferior, this ratio is equal to that of item 2 to item 1 , or 1.8.

The following approximate rules may therefore be given for the strength of a square slab of plain concrete.

Assuming the strength when supported on two edges and under a concentrated load equals 1 , then the strength when similarly supported and carrying a uniform load equals 2 . When the slab is supported on four edges and carries a concentrated load the strength equals 2 , and when supported on four edges and carrying a uniform load the strength equals 4 . These rules only apply when the slab is evenly bedded-that is when, as in practice, it is made in one piece with the cross girders. It will be noticed that the tensile strength of the plain concrete, as calculated from item 7 , Table XI, is $320 \mathrm{lbs}$. per square inch. This is about 25 per cent. of the compressive strength, and is higher than was expected.

With specimens of different thicknesses tested on four edges, the transverse strength varies approximately as the square of the thickness, when this is small, increasing slightly more rapidly for thicker slabs (see Fig. 3). This being the same way in which the strength of a beam varies, it may be expected that the ratio of the strength 
on four edges to the strength on two edges-that is, 2 or $2 \cdot 5$-will remain the same for any square slab, whatever the dimensions are, which fails by direct tension.

Slabs Reinforced with Expanded Metal.-Although many reinforced specimens were tested very few failed in direct tension. In all these results two things make comparisons difficult. First, there is a tendency for the meshes to elongate in one direction, and to close up in another, the slightest elongation being fatal. Secondly, the reinforcement in a slab tested on four edges had to withstand stresses in two directions, while in a slab tested on two edges the same amount of reinforcement was available to withstand the stresses in one direction only. This fact made the strength on two edges proportionately greater than that on four edges.

Table XII has been prepared from Tables $V$ and IX. The bedding in all these cases was good, and it will be seen that for No. 5 expanded metal the ratio of the strength when supported on four edges to the strength when supported on two edges is equal to $\frac{6 \cdot 03}{3 \cdot 81}$ or $1 \cdot 58$, and for No. 22 expanded metal this ratio is $1 \cdot 47$. The square slab reinforced with expanded metal and supported on four edges is therefore only $1 \cdot 5$ times stronger as when supported on two edges.

Diagonal Tension.- -Since the concrete is not properly elastic the computation of the actual diagonal-tension stress will be probably inaccurate, but a simple empirical rule can be framed, by which it is possible to find if a beam or slab is liable to fail in this manner or not. The magnitude of the diagonal tension is practically independent of the amount of reinforcement used, and depends partly on the direct tensile stress in the concrete, but chiefly upon the shearing stress at the supports. From this it seems possible that there is a limiting value for the average shear stress above which fracture by diagonal tension is to be expected.

With regard to the failure of slabs supported on four edges it should be noted that the cracks in this form of failure are circular in shape, the diameter of the circle being equal to the length of the side of the slab. The average shearing area along these cracks is equal to $\pi d t$; where $d$ is the side of the slab, and $t$ the thickness down to the reinforcement. The average shearing stress is therefore the quotient of the total load divided by $\pi d t$.

In the case of a slab supported on two edges, the shearing area is $2 d t$, and the average shearing stress is obtained by dividing the total load by this amount.

If the limiting average shear stress is the same in both cases, the

[THE INST. C.E. VOL. CLXXXV.] 
total loads being approximately the ultimate transverse strengths, it follows that the ratio of the strength supported on four edges to that on two is equal to $\pi / 2$ or $1 \cdot 57$.

This value agrees with that obtained from Tables V and VI (i.e. $1 \cdot 5$ ), so that the foregoing reasoning appears to be rational.

The limiting values of the average shear stress for all the specimens in Tables $\mathrm{V}$ and VI which failed by diagonal tension are given in Table XIII. These values have been calculated by dividing the breaking load by the shearing area, that is by 125 in the case of a slab supported on four edges, and by 80 when tested on two edges. It may be seen that the limiting value of the average shear stress is practically identical in both cases, the average value being $125 \mathrm{lbs}$. per square inch, which is exactly 10 per cent. of the ultimate compressive stress. It is concluded, therefore, that failure by diagonal tension is likely to take place as soon as the average shear stress reaches 10 per cent. of the ultimate compressive stress in the concrete. This rule applies to square slabs whether supported on two edges or four, provided that the average shearing stress is determined in the manner described; and the rule may probably be applied to beams which have no diagonal reinforcement.

In order to design a piece which will be safe against failure by diagonal tension, a factor of safety of four should be used, and so the average shearing stress should not be more than $2 \frac{1}{2}$ per cent. of the compressive strength of the concrete. If this safe limit is exceeded, the only courses open would be either to increase the thickness of the slab without increasing the amount of reinforcement, or to reduce the distance between the cross beams, and to decrease the amount of reinforcement. An alternative would be to reinforce the slab by some method which provides diagonal reinforcement. The loads which usually come on floor-slabs, however, are such that the shearing stress is generally well within the safe limit.

Adhesion in Slabs Reinforced with Plain Wires.-Slabs Nos. 94 to 96, Table VII, failed by the plain wire reinforcement slipping through the concrete. An extensive series of experiments was made on the adhesion of concrete to wires similar to those used in the reinforcement. The average value for adhesion obtained from these experiments was 200 lbs. per square inch; whereas the adhesion calculated from the total load carried by the slabs when reinforced with the same wires averaged $430 \mathrm{lbs}$. per square inch. The discrepancy between these values is thus explained. The value $200 \mathrm{lbs}$. per square inch was obtained by dividing the force required to pull out 
a wire embedded 6 inches in concrete by the area of the surface of the wire in contact, that is, it was the average adhesion of the wire; but in an adhesion specimen the value in pounds per square inch ranges from a minimum value at the embedded end of the bar or wire to a maximum value at the other end, the average value being less than the maximum. This may be illustrated by Figs. 6 , in which $\mathrm{AB}$ represents an unstressed adhesion specimen, and CD shows, in an exaggerated way, what takes place when the load is applied. As the steel is stressed it elongates so that $\mathrm{CD}$ is longer than A B. It follows, therefore, that the concrete at $\mathrm{D}$ is deformed more than that at $C$, and consequently exerts a greater adhesion

Figs. 6.

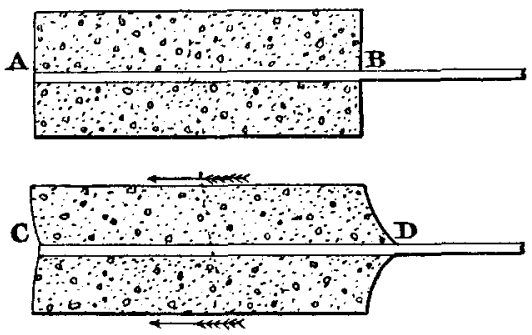

stress on the bar. When the adhesion stress at $D$ reaches its maximum value the bar pulls out. In the cases of the wires under consideration $200 \mathrm{lbs}$. per square inch was the average, and $430 \mathrm{lbs}$. per square inch was probably the maximum value for the adhesion. Using a factor of safety of four the safe adhesion is about $100 \mathrm{lbs}$. per square inch for wires slightly rusty. The disadvantage of using plain smooth rods or wires over deformed rods, is that if disturbed by an accidental blow before the concrete has set the adhesion is very much reduced. This was frequently noticed during the tests, and for the same reason a safe adhesion stress of 50 or 75 lbs. per square inch is of ten specified.

\section{General Conclustons as to the Reinforcement of Slabs.}

Galvanized-iron wire-netting is unsuitable as a reinforcement, since it is made from thin annealed wire which stretches under light loads. As it is so light, several layers would have to be used.

Expanded metal is made in sheets of any convenient size up to 16 feet long, of various weights from the lightest to the heaviest which is likely to be required for slab reinforcement. 
It has many advantages which are not possessed by bar reinforcements. It is convenient to lay in place, while bars have to be laid separately and tied at the intersections. Its shape also prevents any chance of it slipping through the concrete. When a slab reinforced with expanded metal fails by direct tension, the failure is not so sudden as when a slab reinforced with straight wires fails by lack of adhesion. It has high tensile strength even at the intersections. Where it has been bent it will carry 66,000 lbs. per square inch, and the yield-point is near the ultimate strength. Its one disadvantage is its liability to stretch by alteration of the shape of the mesh. Of course, the concrete tends to prevent this, but a very slight stretch as a rule means the failure of the slab.

The ratio of the diagonals of the mesh is about $2 \cdot 5$ to 1 , so that a single mesh carrying a force of $2 \cdot 5$ in the direction of the longer diagonal, and a force 1 in the direction of the other diagonal, is in equilibrium, that is, its shape has no tendency to alter. This condition is probably obtained if the metal is used to reinforce a rectangular slab supported on four edges, the ratio of the sides of which is $2 \cdot 5$, the long way of the mesh being parallel to the shortest side. In a slab whose sides bear this ratio the full strength of the reinforcement would be obtained if the slab were designed to be safe against compression and diagonal tension.

Wire or plain bar reinforcement, where the longitudinal and transverse reinforcement are not interwoven (Monier system), has the disadvantage that the bars are troublesome to lay, and are very liable to be displaced in ramming; further, if the metal is notrusty, or if it is displaced in the slightest degree before the concrete has set, the adhesion is seriously weakened, and sudden failure may result. The advantages of this method are that, as the reinforcement is placed parallel to the supports, only direct stresses occur; and in rectangular slabs the longitudinal and transverse reinforcement may be proportioned to resist unequal bending in the two directions.

Woven wires on the Cottancin system are less likely to slip through the concrete. They are, however, liable to a partial straightening out, thus causing failure unless they have been pulled quite tight before the concrete is laid. Slabs reinforced in this manner gave ample warning before collapsing.

The ideal reinforcement for slabs, therefore, would seem to consist of two sets of straight wires crossing at right angles, welded or otherwise firmly fixed at the intersections, thus forming a mesh which could be laid in sheets with the wires parallel to the supports. 


\section{Influence of Percentage of Water on Strexgth of the Concrete Used.}

A series of experiments was made on the concrete in order to find the effect of the percentage of water used in mixing on the increase in strength of the concrete with age, the materials being the same as those used in the slabs. The specimens were made in three sets, with 6,8 and 10 per cent. by weight of water. The amount of water used in mixing the concrete for the slabs was $8 \cdot 5$ per cent.

A mixture like damp sand was obtained with 6 per cent. of water, from which mixture no water was expelled by vigorous ramming. A mixture convenient to handle and which quaked when rammed was given by 8 per cent. of water; and finally, with 10 per cent. of water, a very thin mixture resulted which had to be handled quickly as it ran off the shovel.

The specific gravity of each specimen was found at the time of making, and so the density of each specimen was calculated in order to see how this compared with the compressive strength.

These specimens were tested at 1,2,3 and 4 months, and the results are given in Table XIV, each item being the average of tests on three specimens. The thirty-six specimens for these tests had, of course, to be made in batches. In spite of all the precautions which were taken, it is evident from the density column that, in the case of the 6-per-cent. specimens, the three tested at 3 and 4 months were not so well made as those tested at 1 and 2 months. The fact that the former were made first may explain this. The strength of the concrete mixed with 8 per cent. of water and 3 months old was 1,250 lbs. per square inch. This is taken as the compressive strength in the upper layer of the slabs.

From these tests it is clearly seen that dry, well-rammed concrete is stronger than the wet concrete which must be used in reinforced work.

All the experiments described were made in the Civil Engineering laboratories of the University of Birmingham.

The Paper is accompanied by two sheets of drawings and fourteen Tables, from which the Figures in the text and the following Appendix have been prepared; there are also two photographs. 


\section{A P PENDIX.}

Table I.--Plain Concrete Slabs $2 \frac{1}{2}$ Inches Thick carrying Unifonm LOADS.

\begin{tabular}{|c|c|c|c|c|c|}
\hline $\begin{array}{c}\text { Test } \\
\text { Number. }\end{array}$ & $\begin{array}{c}\text { Edges } \\
\text { Supported. }\end{array}$ & $\begin{array}{l}\text { Distributed } \\
\text { Ioad. }\end{array}$ & $\begin{array}{l}\text { Total } \\
\text { Load. }\end{array}$ & $\begin{array}{c}\text { Average } \\
\text { Load. }\end{array}$ & Remarks. \\
\hline & & $\begin{array}{c}\text { Lbs. per } \\
\text { Square In. }\end{array}$ & Tons. & I'ons. & \multirow{7}{*}{$\begin{array}{l}\text { Nos. } 7 \text { to } 12 \text { made from a cement } \\
\text { which had been exposed to } \\
\text { damp, hence inferior strength. } \\
\text { Nos. } 7 \text { to } 10 \text { were bedded on } \\
\text { four layers of felt paper instead } \\
\text { of plaster. }\end{array}$} \\
\hline 7 & 4 & $8 \cdot 0$ & $1 \cdot 29$ & \multirow{6}{*}{0.64} & \\
\hline 8 & 4 & $7 \cdot 0$ & $1 \cdot 13$ & & \\
\hline 9 & 4 & $6 \cdot 5$ & $1 \cdot 05$ & & \\
\hline 10 & 4 & $7 \cdot 0$ & $1 \cdot 13$ & & \\
\hline 11 & 2 & $3 \cdot 5$ & 0.53 & & \\
\hline 12 & 2 & $4 \cdot 9$ & 0.75 & & \\
\hline 22 & 4 & $32 \cdot 0$ & $5 \cdot 16$ & $5 \cdot 08$ & \multirow{2}{*}{$\begin{array}{l}\text { Assoc. Portland Cement Manu- } \\
\text { facturers' cement. }\end{array}$} \\
\hline 23 & 4 & $31 \cdot 0$ & $5 \cdot 00$ & & \\
\hline 30 & 4 & $20 \cdot 0$ & $3 \cdot 23$ & \multirow{6}{*}{$3 \cdot 10$} & \multirow{6}{*}{$\begin{array}{c}\text { Nos. } 30 \text { onwards made from } \\
\text { "Ferrocrete" cement. }\end{array}$} \\
\hline 31 & 4 & $19 \cdot 5$ & $3 \cdot 14$ & & \\
\hline 80 & 4 & $21 \cdot 0$ & $3 \cdot 39$ & & \\
\hline 81 & 4 & $19 \cdot 0$ & $3 \cdot 06$ & & \\
\hline 33 & 2 & $7 \cdot 4$ & $1 \cdot 39$ & & \\
\hline 34 & 2 & $9 \cdot 1$ & $1 \cdot 13$ & & \\
\hline
\end{tabular}


Papers.] PLAIN AND REINFORCED CONCLETE SLABS.

Table II.-The Effect of Vartation in Thichness of Plain Slabs.

(All specimens tested on four edges with uniform load.)

\begin{tabular}{|c|c|c|c|c|c|}
\hline $\begin{array}{c}\text { Test } \\
\text { Number. }\end{array}$ & Thickness. & $\begin{array}{c}\text { Distributed } \\
\text { Load. }\end{array}$ & $\begin{array}{l}\text { Total } \\
\text { Load. }\end{array}$ & $\begin{array}{c}\text { Average } \\
\text { Load. }\end{array}$ & Remarks. \\
\hline 74 & $\begin{array}{r}\text { Inches. } \\
1.50\end{array}$ & $\begin{array}{c}\text { Lbs. per } \\
\text { Square Inch. } \\
6 \cdot 6\end{array}$ & $\begin{array}{l}\text { Tons. } \\
1 \cdot 06\end{array}$ & \multirow{4}{*}{$1 \cdot 07$} & \multirow{6}{*}{ Badly bedded. } \\
\hline 76 & $1 \cdot 50$ & $8 \cdot 4$ & $1 \cdot 35$ & & \\
\hline 78 & $1 \cdot 50$ & 5 & 0.81 & & \\
\hline 70 & $2 \cdot 06$ & 11 & $1 \cdot 78$ & & \\
\hline 72 & $2 \cdot 00$ & $9 \cdot 6$ & $1 \cdot 55$ & \multirow[t]{2}{*}{$1 \cdot 66$} & \\
\hline 75 & $2 \cdot 00$ & $10 \cdot 3$ & $1 \cdot 66$ & & \\
\hline 71 & $3 \cdot 00$ & 22 & $3 \cdot 55$ & & \multirow{4}{*}{ Badly bedded. } \\
\hline 73 & $3 \cdot 00$ & 20 & $3 \cdot 23$ & \multirow{3}{*}{$7 \cdot 78$} & \\
\hline 77 & $3 \cdot 50$ & 49 & $7 \cdot 90$ & & \\
\hline 79 & $3 \cdot 50$ & $47 \cdot 5$ & $7 \cdot 66$ & & \\
\hline
\end{tabular}

These results are plotted in Fig. 3 .

Table III.-SLabs Reinforeed with Wire-Netting and SUPported ON FOUR EDGES.

\begin{tabular}{c|c|c|c|c}
\hline $\begin{array}{c}\text { Test } \\
\text { Number. }\end{array}$ & $\begin{array}{c}\text { Number of } \\
\text { Layers. }\end{array}$ & $\begin{array}{c}\text { Distributed } \\
\text { Load. }\end{array}$ & $\begin{array}{c}\text { Total } \\
\text { Load. }\end{array}$ & Remarks. \\
\hline & & $\begin{array}{c}\text { Lbs. per } \\
\text { square Inch. }\end{array}$ & $\begin{array}{c}\text { Tons. } \\
. .\end{array}$ & $5 \cdot 08$ \\
24 & 0 & 33 & $5 \cdot 31$ & From Table I. \\
25 & 1 & 26 & $4 \cdot 19$ & This reading \\
26 & 1 & 36 & $5 \cdot 80$ & \\
27 & 2 & 38 & $6 \cdot 28$ & \\
28 & 2 & 43 & $6 \cdot 92$ & \\
29 & 4 & 49 & $7 \cdot 89$ & \\
\hline
\end{tabular}


Table IV.-Ehfect of Position of Reinforcement.

\begin{tabular}{c|c|c|c}
\hline Test Number. & $\begin{array}{c}\text { Depth of } \\
\text { Reinforcement. }\end{array}$ & Distributed Load. & Total Load. \\
\hline 108 & $\begin{array}{l}\text { Inches. } \\
2.25\end{array}$ & $\begin{array}{c}\text { Lbs. per Square Inch. } \\
48\end{array}$ & $\begin{array}{c}\text { Tons. } \\
\ldots\end{array}$ \\
\hline 109 & 1.875 & $\ldots$ & 6.93 \\
110 & 1.75 & 43 & 6.93 \\
112 & 1.5 & 37.5 & 5.88 \\
& & 30 & 4.83 \\
\hline
\end{tabular}

Table V.-Slabs Retwforcfd with Expanded Metal and Supported on Four EDaEs.

(Variation of transverse strength with amount of reinforcement employed.)

\begin{tabular}{|c|c|c|c|c|c|c|}
\hline $\begin{array}{c}\text { T'est } \\
\text { Number. }\end{array}$ & $\begin{array}{l}\text { Maker's } \\
\text { No. } \\
\text { for Exp. } \\
\text { Metal. }\end{array}$ & $\begin{array}{l}\text { Weight of } \\
\text { Reinforce- } \\
\text { ment. }\end{array}$ & $\begin{array}{c}\text { Distributed } \\
\text { Ioad. }\end{array}$ & $\begin{array}{l}\text { Total } \\
\text { Load. }\end{array}$ & $\begin{array}{l}\text { Average } \\
\text { Load. }\end{array}$ & Remarks. \\
\hline 36 & 5 & $\begin{array}{c}\text { Lbs. per } \\
\text { square Foot. } \\
0.295\end{array}$ & $\begin{array}{l}\text { Lbs. per } \\
\text { square Inch. } \\
32\end{array}$ & $\begin{array}{l}\text { Tons. } \\
5 \cdot 16\end{array}$ & T'ons. & Metal Broken. \\
\hline 51 & 5 & 0.295 & $42 \cdot 75$ & $6 \cdot 90$ & & \\
\hline 39 & 6 & 0.390 & $35 \cdot 25$ & $5 \cdot 68$ & & \\
\hline 40 & 6 & 0.390 & 42 & $6 \cdot 77$ & $6 \cdot 46\{$ & Signs of yielding of \\
\hline 41 & 6 & 0.390 & 43 & 6.93 & & \\
\hline 42 & 22 & 0.615 & 42 & $6 \cdot 77$ & & \\
\hline 43 & 22 & 0.615 & 40 & $6 \cdot 45$ & $6 \cdot 93$ & \\
\hline 44 & 22 & 0.615 & 47 & $7 \cdot 58$ & & \\
\hline 58 & 35 & $\mathbf{1} \cdot 020$ & 47 & $7 \cdot 58$ & & Nos. 58 to $66 \mathrm{pr}$ \\
\hline 59 & 35 & $1 \cdot 020$ & 37 & $5 \cdot 96$ & $6 \cdot 85$ & bably failed by \\
\hline 60 & 35 & $1 \cdot 020$ & $43 \cdot 5$ & $7 \cdot 01$ & (1) & \\
\hline 61 & 21 & $1 \cdot 280$ & 45 & $7 \cdot 25$ & $7 \cdot 25$ & \\
\hline 64 & 23 & $1 \cdot 416$ & 48 & $7 \cdot 74$ & & \\
\hline 65 & 23 & $1 \cdot 416$ & 35 & $5 \cdot 64$ & $6 \cdot 77$ & \\
\hline 66 & 23 & $1 \cdot 416$ & 43 & $6 \cdot 93$ & & \\
\hline 67 & 19 & 0.638 & $42 \cdot 5$ & $6 \cdot 85$ & & $\frac{3}{4}$-inch mesh metal. \\
\hline 68 & 19 & 0.638 & 41 & $6 \cdot 61$ & $6 \cdot 58$ & \\
\hline 69 & 19 & 0.638 & 39 & $6 \cdot 29$ & & Cracked in storage. \\
\hline
\end{tabular}

These readings are plotted in Fig. 4. 
Table VI.-Slabs Reinforced with Expanded Metal and Supported on Two EDGes.

\begin{tabular}{|c|c|c|c|c|c|c|}
\hline $\begin{array}{c}\text { Test } \\
\text { Number. }\end{array}$ & $\begin{array}{c}\text { Maker's } \\
\text { No. } \\
\text { for Exp. } \\
\text { i Metal. }\end{array}$ & $\begin{array}{l}\text { Weight of } \\
\text { Reinforce- } \\
\text { ment. }\end{array}$ & $\begin{array}{l}\text { Distributed } \\
\text { Load. }\end{array}$ & Total Load. & $\begin{array}{c}\text { Average } \\
\text { Load. }\end{array}$ & Remarks on Failure. \\
\hline 113 & 5 & $\begin{array}{c}\text { Llss. per } \\
\text { Sq. Foot. } \\
0.295\end{array}$ & $\begin{array}{l}\text { Lbs. per } \\
\text { Sy. Inch. } \\
25 \cdot 0\end{array}$ & $\begin{array}{l}\text { Tons. } \\
3 \cdot 81\end{array}$ & $\begin{array}{c}\text { Tons. } \\
3 \cdot 81\end{array}$ & Metal broken. \\
\hline 45 & 22 & $0 \cdot 615$ & $28 \cdot 5$ & $4 \cdot 35$ & \multirow{2}{*}{$4 \cdot 65$} & \multirow{2}{*}{ Diagonal tension. } \\
\hline 46 & 22 & 0.615 & $32 \cdot 5$ & $4 \cdot 95$ & & \\
\hline 105 & 22 & 0.615 & $31 \cdot 7$ & $4 \cdot 73$ & $4 \cdot 73$ & Stretch of meshes. \\
\hline 54 & 35 & $1 \cdot 02$ & $29 \cdot 0$ & $4 \cdot 43$ & \multirow{2}{*}{$4 \cdot 54$} & \multirow{2}{*}{ Diagonal tension. } \\
\hline 55 & 35 & $1 \cdot 02$ & $30 \cdot 5$ & $4 \cdot 65$ & & \\
\hline${ }^{1} 48$ & 22 & 0.615 & $9 \cdot 5$ & $1 \cdot 45$ & \multirow{2}{*}{$1 \cdot 3$} & \multirow{2}{*}{ Stretch of meshes. } \\
\hline 149 & 22 & 0.615 & $7 \cdot 5$ & $1 \cdot 15$ & & \\
\hline${ }^{1} 56$ & 35 & $1 \cdot 02$ & $6 \cdot 5$ & 0.99 & \multirow{2}{*}{$1 \cdot 09$} & \multirow[b]{2}{*}{$"$} \\
\hline${ }^{1} 57$ & 35 & $1 \cdot 02$ & $7 \cdot 7$ & $\mathbf{1} \cdot 18$ & & \\
\hline
\end{tabular}

${ }^{1}$ Supported with long way of mesh parallel to supports.

Table VII.-Slabs Reinforced with Iron WIRE and Supported on FoUR EDGES.

\begin{tabular}{|c|c|c|c|c|}
\hline Test Number. & Reinforcement. & $\begin{array}{l}\text { Distributed } \\
\text { Load. }\end{array}$ & Total Load. & Average Load. \\
\hline 94 & \multirow{3}{*}{ Monier } & $\begin{array}{c}\text { Lbs. per Sq. Inch. } \\
67 \cdot 0\end{array}$ & $\begin{array}{l}\text { Tons. } \\
10 \cdot 96\end{array}$ & Tons. \\
\hline 95 & & $45 \cdot 0$ & $7 \cdot 26$ & $8 \cdot 39$ \\
\hline 96 & & $43 \cdot 0$ & $6 \cdot 94$ & \multirow{4}{*}{$5 \cdot 86$} \\
\hline 97 & \multirow{3}{*}{ Cottancin } & $40 \cdot 5$ & $6 \cdot 53$ & \\
\hline 98 & & $31 \cdot 0$ & $5 \cdot 00$ & \\
\hline 99 & & $37 \cdot 5$ & $6 \cdot 05$ & \\
\hline
\end{tabular}


Table VIII.-Plain Concrete Slabs under Concentrated Loads.

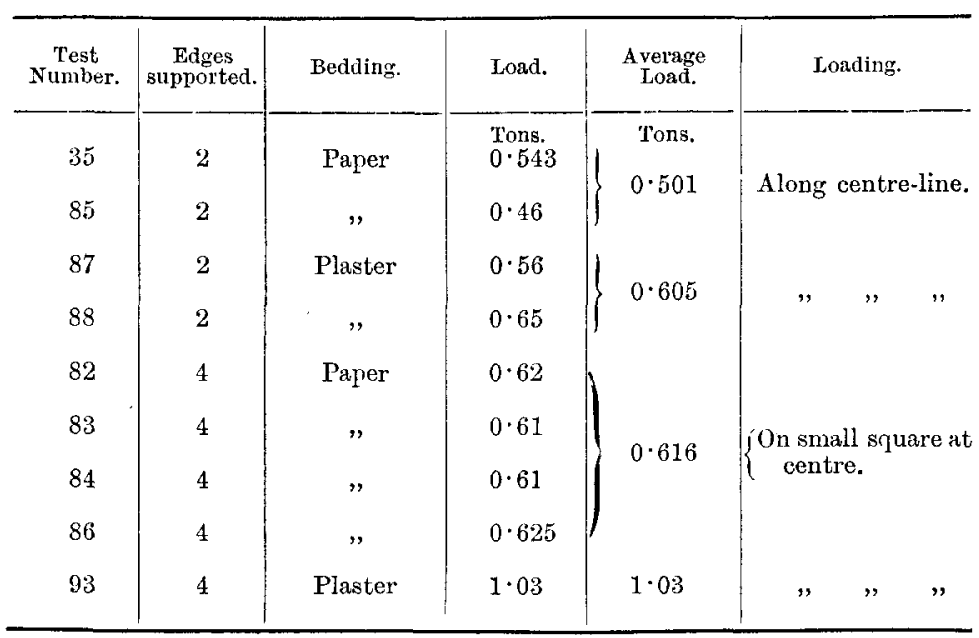

Table IX.-Reinforced Concrete Slabs under Concentrated Loads. (Method of locading, as in Table VIIII.)

\begin{tabular}{|c|c|c|c|c|c|c|}
\hline $\begin{array}{c}\text { Test } \\
\text { Number. }\end{array}$ & $\begin{array}{c}\text { Maker's } \\
\text { No. } \\
\text { for Exp. } \\
\text { Metal. }\end{array}$ & $\begin{array}{c}\text { Edges } \\
\text { supported. }\end{array}$ & Bedding. & Load. & $\begin{array}{l}\text { Average } \\
\text { Load. }\end{array}$ & Failure. \\
\hline 50 & 22 & 2 & Paper & $\begin{array}{l}\text { Tons. } \\
2 \cdot 38\end{array}$ & Tons. & Diagonal tension. \\
\hline 100 & 22 & 2 & Plaster & $2 \cdot 60$ & & Direct tension. \\
\hline 52 & 35 & 2 & Paper & $3 \cdot 12$ & & \\
\hline 53 & 35 & 2 & ," & $2 \cdot 61$ & & 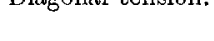 \\
\hline 101 & 22 & 4 & Plaster & $1 \cdot 72$ & & \\
\hline 102 & 22 & 4 & , & $1 \cdot 81$ & & \\
\hline
\end{tabular}


Papers.] PLAIN AND REINFORCED CONCRETE SLABS.

Table X.-Impact Tests.

(Slabs supported on four edges.)

\begin{tabular}{|c|c|c|c|c|c|}
\hline $\begin{array}{c}\text { Test } \\
\text { Number. }\end{array}$ & Type of Slab. & $\begin{array}{c}\text { Fall of } \\
\text { Weight. }\end{array}$ & $\begin{array}{c}\text { Energy per } \\
\text { Blow. }\end{array}$ & $\begin{array}{l}\text { Total } \\
\text { Energy. }\end{array}$ & Remarks. \\
\hline \multirow{4}{*}{90} & \multirow{5}{*}{ Plain concrete } & $\begin{array}{l}\text { Feet. } \\
1 \cdot 25\end{array}$ & $\begin{array}{c}\text { Foot-Lbs. } \\
11 \cdot 6\end{array}$ & Foot-Lbs. & \\
\hline & & $2 \cdot 00$ & $18 \cdot 6$ & \multirow{3}{*}{$89 \cdot 9$} & \\
\hline & & $2 \cdot 75$ & $25 \cdot 6$ & & \\
\hline & & $3 \cdot 66$ & $34 \cdot 1$ & & $\left\{\begin{array}{c}\text { Specimen completely } \\
\text { broken. }\end{array}\right.$ \\
\hline \multirow{2}{*}{91} & & $3 \cdot 04$ & $28 \cdot 3$ & \multirow{2}{*}{$60 \cdot 9$} & (Snecimen only just \\
\hline & ", & $3 \cdot 5$ & $32 \cdot 6$ & & $\{$ broken. \\
\hline 92 & " & $2 \cdot 5$ & $23 \cdot 25$ & $69 \cdot 8$ & Three blows required. \\
\hline 89 & ", & $1 \cdot 5$ & $13 \cdot 95$ & $69 \cdot 8$ & Five blows required. \\
\hline \multirow{6}{*}{103} & \multirow{6}{*}{$\begin{array}{c}\text { No. } 22 \\
\text { expanded } \\
\text { metal } \\
\text { reinforcement }\end{array}$} & $3 \cdot 0$ & $27 \cdot 9$ & \multirow{6}{*}{$172 \cdot 2$} & \multirow{6}{*}{$\begin{array}{l}\text { Small crack formed. } \\
\left\{\begin{array}{c}\text { Small piece broken } \\
\text { away. }\end{array}\right.\end{array}$} \\
\hline & & 42 & $38 \cdot 8$ & & \\
\hline & & $5 \cdot 0$ & $46 \cdot 5$ & & \\
\hline & & $6 \cdot 3$ & $59 \cdot 0$ & & \\
\hline & & $6 \cdot 3$ & $59 \cdot 0$ & & \\
\hline & & $6 \cdot 3$ & $59 \cdot 0$ & & \\
\hline \multirow{2}{*}{104} & \multirow[b]{2}{*}{ ", } & $5 \cdot 92$ & $56 \cdot 0$ & \multirow{2}{*}{$128 \cdot 2$} & Crapted \\
\hline & & $7 \cdot 75$ & $72 \cdot 2$ & & Crackeu. \\
\hline 106 & , & 90 & $83 \cdot 7$ & $167 \cdot 4$ & Two blows required. \\
\hline 107 & ", & $3 \cdot 0$ & $27 \cdot 9$ & $139 \cdot 5$ & Five blows required. \\
\hline
\end{tabular}

Table XI.-Summary of Tests on Plain Concrete Slabs, Compiled From Tabues I AND VIII.

\begin{tabular}{|c|c|c|c|c|c|c|c|}
\hline Item. & Test Number. & $\begin{array}{c}\text { Edges } \\
\text { sup- } \\
\text { ported. }\end{array}$ & Loading. & & $\begin{array}{c}\text { Average } \\
\text { Strength. }\end{array}$ & $\begin{array}{c}\text { Relative } \\
\text { Strengths. }\end{array}$ & Bedding. \\
\hline 1 & 11,12 & 2 & Uniform & . & $\begin{array}{l}\text { Tons. } \\
0 \cdot 64\end{array}$ & $\begin{array}{c}\text { Tons. } \\
. .\end{array}$ & Good. \\
\hline 2 & $7-10$ & 4 & , & . & $1 \cdot 15$ & .. & Inferior. \\
\hline 3 & 35,85 & 2 & Concentrated & d. & 0.501 & .. & Inferior. \\
\hline 4 & 87,88 & 2 & $"$ & - & $0 \cdot 605$ & $0 \cdot 49$ & Good. \\
\hline 5 & 82,86 & 4 & " & . & $0 \cdot 616$ & .. & Very bad. \\
\hline 6 & 93 & 4 & , & . & $1 \cdot 03$ & $0 \cdot 82$ & Fairly good. \\
\hline 7 & 33,34 & 2 & Uniform & . & $1 \cdot 26$ & $1 \cdot 0$ & Good. \\
\hline 8 & $30,31,80,81$ & 4 & , & . & $3 \cdot 10$ & $2 \cdot 46$ & Good. \\
\hline
\end{tabular}


Table XII.--Summary of Tests on Slabs Reinforced with Expanded Metal, Compiled from Tables V and IX.

\begin{tabular}{|c|c|c|c|c|c|c|}
\hline Item. & Test Number. & $\begin{array}{c}\text { Expanded } \\
\text { Metal } \\
\text { Number. }\end{array}$ & $\begin{array}{c}\text { Edges } \\
\text { Supported. }\end{array}$ & Loading. & & Average Load. \\
\hline 1 & 113 & 5 & 2 & Uniform . & • & $\begin{array}{l}\text { Tons. } \\
3 \cdot 81\end{array}$ \\
\hline 2 & 36,51 & 5 & 4 & , & . & $6 \cdot 03$ \\
\hline 3 & 42,44 & 22 & 4 & $n$ & . & $6 \cdot 92$ \\
\hline 4 & 105 & 22 & 2 & " & . & $4 \cdot 73$ \\
\hline 5 & 100 & 22 & 2 & Concentrated & & $2 \cdot 60$ \\
\hline 6 & 101,102 & 22 & 4 & , & . & $1 \cdot 76$ \\
\hline
\end{tabular}

Table XIII.-Averagis Shfaring Stress at Failure, Calculated from TABLES V AND VI.

\begin{tabular}{|c|c|c|c|}
\hline Test Number. & Edges Supported. & Total Load. & Average Shear Stress. \\
\hline 42 & 4 & $\begin{array}{l}\text { Tons. } \\
6 \cdot 77\end{array}$ & $\begin{array}{l}\text { Lbs. per Sq. In. } \\
122\end{array}$ \\
\hline 43 & 4 & $6 \cdot 45$ & 116 \\
\hline 44 & 4 & $7 \cdot 58$ & 136 \\
\hline 58 & 4 & $7 \cdot 58$ & 136 \\
\hline 59 & 4 & $5 \cdot 96$ & 107 \\
\hline 60 & 4 & $7 \cdot 01$ & 126 \\
\hline 61 & 4 & $7 \cdot 25$ & 130 \\
\hline 64 & 4 & $7 \cdot 74$ & 139 \\
\hline 65 & 4 & $5 \cdot 64$ & 101 \\
\hline 66 & 4 & $6 \cdot 93$ & 124 \\
\hline 45 & 2 & $4 \cdot 35$ & 122 \\
\hline 46 & 2 & $4 \cdot 95$ & 138 \\
\hline 54 & 2 & $4 \cdot 43$ & 124 \\
\hline 55 & 2 & $4 \cdot 65$ & 130 \\
\hline
\end{tabular}


Papers.] PLAIN AND REINFORCED CONCRETE SLABS.

Table XIV.--Influence of Amount of Water on Strength of Conchete.

\begin{tabular}{c|c|c|c|c}
\hline Item. & Water. & Age. & $\begin{array}{c}\text { Average Compressive } \\
\text { Strength. }\end{array}$ & Density. \\
\hline 1 & $\begin{array}{c}\text { Per Cent. } \\
6\end{array}$ & $\begin{array}{c}\text { Days. } \\
38\end{array}$ & $\begin{array}{c}\text { Lbs. per Square Inch. } \\
1,247\end{array}$ & 0.839 \\
2 & 6 & 64 & 1,513 & 0.839 \\
3 & 6 & 93 & 1,270 & 0.795 \\
4 & 6 & 121 & 1,350 & 0.795 \\
5 & 8 & 37 & 791 & 0.843 \\
6 & 8 & 66 & 1,253 & 0.843 \\
7 & 8 & 91 & 1,040 & 0.828 \\
8 & 8 & 132 & 1,260 & 0.828 \\
9 & 10 & 35 & 390 & 0.821 \\
10 & 10 & 64 & 750 & 0.821 \\
11 & 10 & 89 & 860 & 0.812 \\
12 & 10 & 130 & 1,010 & 0.812 \\
\hline
\end{tabular}

